\title{
Bronchial-pulmonary adenocarcinoma subtyping relates with different molecular pathways
}

\author{
Vítor Sousa ${ }^{a, b, *}$, Bruno Bastos ${ }^{a}$, Maria Silva ${ }^{a}$, Ana Maria Alarcão ${ }^{a}$, Lina Carvalho ${ }^{a, b}$ \\ a IAP-FMUC-Institute of Pathology, Faculty of Medicine, University of Coimbra, Coimbra, Portugal \\ b Pathology Institute, Coimbra University Hospital (HUC-CHUC), Coimbra, Portugal
}

Received 30 October 2013; accepted 30 May 2014

Available online 6 March 2015

KEYWORDS
Lung;
Adenocarcinoma;
APC;
BCL2;
Cyclin D1;
EGFR;
ERCC1;
HER2;
LRP;
MRP

* Corresponding author.

E-mail address: vitorsousa77@netcabo.pt (V. Sousa).

\begin{abstract}
Lung cancer is one of the most common cancers in the world with a high mortality rate. We analyzed 45 surgical samples of the adenocarcinoma, 13 with lymph node metastasis. APC, BCL2, chromogranin A, CK 5/6/18 (LP34), CK20, CK7, cyclin D1, EGFR, ERCC1, HER2, Ki67, LRP, MRP, P53, RB and TTF1 expressions were evaluated by immunohistochemistry (IHC).

Higher Ki67, APC, ERCC1 expressions and lower TTF1 expression were identified in advanced stages (IIA and IIIA) of adenocarcinomas, which reflect a more aggressive, less differentiated, possibly a non-TRU adenocarcinoma.

Acinar, micropapillary and BA/lepidic adenocarcinoma patterns were the most similar patterns and papillary was the most different pattern followed by solid pattern, according to expression of these markers. Different adenocarcinoma patterns are engaged with different molecular pathways for carcinogenesis, based on the differences of expression. Acinar, BA/lepidic and micropapillary showed higher TTF1 expression (type TRU), and papillary and solid patterns revealed less TTF1 expression, exhibiting a non-TRU/bronchial phenotype. Solid pattern revealed lower HER2 and higher EGFR and ERCC1 (this compared to papillary) expression; papillary higher HER2 and lower ERCC1 expressions; micropapillary higher RB expression; and acinar lower ERCC1 and higher EGFR expressions. Ciclin D1 seems to have more importance in acinar and BA/lepidic patterns than in micropapillary. ERCC1 protein expression in micropapillary, solid and BA/lepidic patterns may indicate DNA repair activation. Inhibition of apoptosis could be explained by BCL2 overexpression, present in all adenocarcinoma patterns. MRP-1 and LRP were overexpressed in all patterns, which may have implications for drug resistance.

Further studies are needed to interpret these data regarding to therapy response in advanced staged bronchial-pulmonary carcinomas.

(c) 2013 Sociedade Portuguesa de Pneumologia. Published by Elsevier España, S.L.U. All rights reserved.
\end{abstract}




\section{Introduction}

Tobacco, environmental and genetic factors and several lung diseases contribute to lung cancer carcinogenesis. Lung cancer is one of the most common cancer diagnosed, and has also the highest mortality rate due to the advanced stages at time of diagnosis, and when the options for treatment have to be understood as personalized therapy..$^{1-8}$

Bronchial-pulmonary carcinomas consist of small cell lung cancer (SCLC), squamous cell carcinoma (SCC), adenocarcinoma, large cell carcinoma and sarcomatoid/pleomorphic carcinomas. ${ }^{8}$ Adenocarcinoma is the most common type in non-smokers and its incidence has increased in recent years, developing after terminal respiratory unit (TRU) but also recognized in respiratory epithelium. ${ }^{8-10}$ Adenocarcinoma pure patterns are recognized [acinar, papillary, micropapillary, BA (bronchioloalveolar/lepidic/AIS-adenocarcinoma in situ), solid with mucin production] but mixed type predominates. Differences between the subtype/patterns of adenocarcinoma should be taken into account to improve diagnosis, prognosis and as an enhancement in therapy selection. ${ }^{8,10}$

Cytokeratin 7 (CK7), high weight molecular cytokeratins (HWMC) like CK5/6, CK20, chromogranin A and TTF1 are currently used in lung cancer diagnosis. ${ }^{11,12} \mathrm{Ki67}$ is a cell proliferation marker with prognostic value. ${ }^{13-15}$ In the apoptosis pathway, p53 induces Bax transcription and reduces bcl2. Bcl2/Bax ratio is negative in lung carcinomas. ${ }^{16}$ Inactivation of RB pathway is considered a requirement for lung carcinogenesis. ${ }^{16}$ Adenomatous polyposis coli (APC) gene is involved in the canonical Wnt/ $\beta$-catenin signal transduction. $A P C$ is mutated in liver, colorectal adenomas and lung tumors. ${ }^{17}$ Cyclins D (D1, D2, and D3) are activators of cyclin-dependent kinases cdk4 and cdk6, to translate growth signals into cell cycle progression, leading to proliferation. ${ }^{18,19}$ Cyclin D1 overexpression and pRB inactivation indicates a poor prognosis. ${ }^{20}$

Bcl2 as an anti-apoptotic protein has a more important role in neuroendocrine (NE) lung cancer than in other bronchial-pulmonary carcinomas. ${ }^{21}$ Excision repair cross-complementing 1 (ERCC1) genetic polymorphisms may affect patient's response to platinum-based chemotherapy. ${ }^{22,23}$ However, another study concluded that patients with a bronchial-pulmonary carcinoma with high ERCC1 expression have a better prognosis than those with low expression. ${ }^{24}$ Multidrug Resistance Protein 1 (MRP-1) and lung resistance-related protein (LRP) may confer resistance to cytotoxic and antiviral drugs. ${ }^{25-31}$

EGFR and HER2 play a central role in tumorigenesis. ${ }^{32,33}$ Targeting those receptors provides a unique approach for treating EGFR/HER2 expressing cancers. ${ }^{34,35}$ The most common alteration of HER2 is overexpression/amplification; mutations are less frequent. ${ }^{33,35,36}$ The activated receptors trigger Ras-Raf-MEK (mitogen-activated and extracellular signal regulated kinase), ERK1 and ERK2 (extracellular-signal regulated kinase 1 and 2) pathways leading to cell growth, mTOR (mammalian target of rapamycin) pathway leading to protein synthesis, and PI3K-AKT (phosphatidylnositol-2 kinase Akt) pathway sustaining cell survival. ${ }^{36}$

The objectives of this work were to validate a small differentiation IHC panel, evaluate protein expression of different genes according to different adenocarcinoma patterns, and correlate this expression with cell pathways of progression and drug resistance, in order to understand bronchial-pulmonary adenocarcinoma carcinogenesis. Another objective was to verify possible differences of gene expression in adenocarcinoma taking into account variables such as gender, age, smoking and different tumor stages. The global intention of this project is to acquire knowledge which can be applied in the diagnosis and prognosis evaluation of bronchial-pulmonary adenocarcinoma and its subtypes in order to define individual treatment.

\section{Materials and methods}

\section{Materials}

Surgical samples of bronchial-pulmonary adenocarcinomas $(n=45)$ covering all subtypes recognized by WHO/2004 were randomly selected and staged by the 2010 TNM system; the ERS/ATS proposal was also applied. At least two sections of each tumor and sections of lymph node metastasis were selected (Table 1). ${ }^{12,37}$

\section{Methods}

CK7, TTF1, CK20, CK 5/6/18 (LP34), chromogranin A, Ki67, P53, RB, BCL2, cyclin D1, APC, ERCC1, LRP, MRP-1, EGFR, and HER2 expressions were evaluated by immunohistochemistry (IHC). IHC was performed on formalin-fixed, paraffin-embedded tissue samples in automatic immunostainer (Autostainer 360 - LabVision ${ }^{\circledR}$ ). Streptavidin biotin protocol was applied according to the manufactures indications for each antibody. Three-micrometer tissue sections were placed on coated slides and allowed to dry overnight. After deparaffinization and rehydration, antigen retrieval was performed according to Table 2. Endogenous peroxidase activity was quenched using $15 \mathrm{~min}$ incubation in $3 \%$ diluted hydrogen peroxide $\left(\mathrm{H}_{2} \mathrm{O}_{2}\right)$. For blocking non-specific binding, Ultra V Block (Ultra Vision $\mathrm{Kit}^{\circledR}$; TP-015-HL) was applied to the sections and then they were incubated at room temperature, with primary antibodies according to Table 2. After washing with phosphate-buffered saline (PBS), slides were incubated with biotin-labeled secondary antibody (LabVision ${ }^{\circledR}$ ) for 15 min. Primary antibody binding was localized in tissues using peroxidase-conjugated streptavidin (LabVision ${ }^{\circledR}$ ) and 3,3-diaminobenzidine tetrahydrochloride (DAB) was used as the chromogen, according to manufacturer's instructions. The slides were counterstained with hematoxylin, dehydrated and mounted. In parallel, known positive (Table 2) and negative controls were used.

Three-micrometer tissue sections were placed on coated slides and allowed to dry overnight. IHC scoring was applied independently by two pathologists who registered the intensity of expression (1 - low expression, 2 - intermediate expression and 3 - high expression) and percentage of stained cells. For statistical analyses we grouped the immunohistochemistry results in 4 categories. For each case we multiplied the intensity of expression by the percentage of staining cells and we used this score for the formation of 
Table 1 Gender ( $M$ - male; $F$ - female), age, smoking status, TNM classification, stage and patterns present (A - acinar; B BA/lepidic; C - papillary; D - micropapillary and E - solid).

\begin{tabular}{|c|c|c|c|c|c|c|}
\hline & Gender & Age & Tobacco & TNM & Stage & Patterns \\
\hline 1 & M & 73 & Non-smoker & pT1aNOMx & IA & $A ; B$ \\
\hline 2 & $\mathrm{~F}$ & 71 & Non-smoker & pT1aNOMx & $\mathrm{IA}$ & $\mathrm{A} ; \mathrm{B}$ \\
\hline 3 & $M$ & 69 & Smoker & pT4NOMx & IIIA & $\mathrm{A} ; \mathrm{B} ; \mathrm{C}$ \\
\hline 4 & $M$ & 75 & Non-smoker & pT1aN2Mx & IIIA & $A ; E$ \\
\hline 5 & $\mathrm{~F}$ & 53 & Non-smoker & pT1aNOMx & $\mathrm{IA}$ & $A ; B$ \\
\hline 6 & $M$ & 76 & Ex-smoker & pT2bNOMx & IIA & $A ; B ; E$ \\
\hline 7 & $\mathrm{~F}$ & 62 & Ex-smoker & $\mathrm{pT} 1 \mathrm{aN} 2 \mathrm{Mx}$ & IIIA & $A ; B ; E$ \\
\hline 8 & $\mathrm{~F}$ & 74 & Non-smoker & pT1aNOMx & IA & $\mathrm{A} ; \mathrm{B} ; \mathrm{E}$ \\
\hline 9 & $\mathrm{~F}$ & 68 & Non-smoker & pT2aNOMx & IB & A; D; E \\
\hline 10 & $\mathrm{~F}$ & 50 & Non-smoker & pT1bN2Mx & IIIA & $A ; E$ \\
\hline 11 & $\mathrm{~F}$ & 57 & Smoker & pT2aNOMx & IB & $A ; E$ \\
\hline 12 & $M$ & 51 & Non-smoker & pT1aN1Mx & IIA & $A ; B$ \\
\hline 13 & $\mathrm{~F}$ & 75 & Non-smoker & pT2aNOMx & IB & A; D; E \\
\hline 14 & M & 85 & Ex-smoker & pT1aNOMx & IA & A; B \\
\hline 15 & $\mathrm{~F}$ & 63 & Smoker & pT2aNOMx & IB & A; B; D \\
\hline 16 & $\mathrm{~F}$ & 55 & Smoker & pT1aNOMx & IA & $\mathrm{A} ; \mathrm{E}$ \\
\hline 17 & $\mathrm{~F}$ & 67 & Smoker & pT1aNOMx & IA & A; B; D \\
\hline 18 & $M$ & 48 & Smoker & pT1aNOMx & IA & $A ; B ; E$ \\
\hline 19 & $M$ & 71 & Non-smoker & pT2aN1Mx & IIA & $A ; D$ \\
\hline 20 & M & 49 & Smoker & pT2aNOMx & IB & A \\
\hline 21 & $\mathrm{~F}$ & 80 & Non-smoker & pT1bNOMx & IA & $A ; D$ \\
\hline 22 & $\mathrm{~F}$ & 68 & Non-smoker & pT2aN1Mx & IIA & $A ; D$ \\
\hline 23 & $M$ & 48 & Non-smoker & pT2bNOMx & IIA & $A ; B$ \\
\hline 24 & $\mathrm{~F}$ & 67 & Non-smoker & pT2aNOMx & IB & A \\
\hline 25 & M & 76 & Ex-smoker & pT1bNOMx & IA & $A ; B$ \\
\hline 26 & $\mathrm{~F}$ & 56 & Non-smoker & pT1aNOMx & IA & A; B; C; D \\
\hline 27 & M & 64 & Smoker & pT2bNOMx & IIA & $\mathrm{A} ; \mathrm{C}$ \\
\hline 28 & $\mathrm{~F}$ & 71 & Non-smoker & pT2aNOMx & IB & A; B; E \\
\hline 29 & $\mathrm{~F}$ & 50 & Smoker & pT2aNOMx & IB & $\mathrm{B} ; \mathrm{E}$ \\
\hline 30 & $\mathrm{~F}$ & 80 & Non-smoker & $\mathrm{pT} 1 \mathrm{aNxMx}$ & IA & $\mathrm{E}$ \\
\hline 31 & M & 56 & Smoker & pT1aNOMx & IA & $A ; B$ \\
\hline 32 & $\mathrm{~F}$ & 56 & Non-smoker & pT1aNOMx & IA & $A ; B$ \\
\hline 33 & $\mathrm{~F}$ & 54 & Non-smoker & pT1aNOMx & IA & B \\
\hline 34 & $M$ & 67 & Smoker & pT2aN1Mx & IIA & $A ; E$ \\
\hline 35 & $\mathrm{~F}$ & 62 & Non-smoker & $\mathrm{pT} 1 \mathrm{bN} 1 \mathrm{Mx}$ & IIA & $A ; C ; D$ \\
\hline 36 & $\mathrm{~F}$ & 68 & Non-smoker & pT1bNOMx & $\mathrm{IA}$ & $\mathrm{A} ; \mathrm{B}$ \\
\hline 37 & $\mathrm{~F}$ & 44 & Non-smoker & pT2bN2Mx & IIIA & $\mathrm{A} ; \mathrm{E}$ \\
\hline 38 & $\mathrm{~F}$ & 52 & Smoker & pT3N1Mx & IIIA & A; B; D \\
\hline 39 & $M$ & 45 & Smoker & pT2aN1Mx & IIA & $\mathrm{A} ; \mathrm{C}$ \\
\hline 40 & $M$ & 61 & Smoker & pT2aNOMx & $\mathrm{IB}$ & A \\
\hline 41 & $\mathrm{~F}$ & 74 & Non-smoker & pT2aNOMx & IB & $A ; D$ \\
\hline 42 & $\mathrm{~F}$ & 74 & Non-smoker & pT2aNOMx & IB & $A ; B$ \\
\hline 43 & M & 73 & Non-smoker & pT2aN1Mx & IIA & $\mathrm{A} ; \mathrm{B}$ \\
\hline 44 & $\mathrm{~F}$ & 60 & Non-smoker & pT1bNOMx & IA & A; B; D \\
\hline 45 & $\mathrm{~F}$ & 79 & Non-smoker & pT2aNOMx & IB & A; B; D \\
\hline
\end{tabular}

each category (category $(-)$ 0-10; (+) 11-100; (++) 101-200; (+++) 201-300) (Table 3)

The non-parametric Wilcoxon-Mann-Whitney test was used to analyze the differences between categories. Hierarchical clustering and Principal Component Analysis (PCA) was made to validate relationships between patterns. We used the software STASTISTICA 7. $P$ values less than 0.05 were considered significant.

\section{Results}

Predominantly mixed-type adenocarcinomas, ${ }^{40}$ three acinar adenocarcinomas, one solid mucin producing adenocarcinoma and one bronchioloalveolar (BA)/lepidic mucinous adenocarcinoma/mucinous adenocarcinoma in situ were studied to validate the different patterns. Forty-two cases (93.3\%) with acinar pattern (being the most prevalent), 
Table 2 Antibodies applied antigen retrieval, dilution and incubation time and staining patterns. RT - room temperature.

\begin{tabular}{|c|c|c|c|c|c|c|}
\hline Primary antibody & Manufacture & Clone & Positive control & $\begin{array}{l}\text { Antigen } \\
\text { retrieval }\end{array}$ & $\begin{array}{l}\text { Dilution and } \\
\text { incubation time }\end{array}$ & $\begin{array}{l}\text { Staining } \\
\text { pattern }\end{array}$ \\
\hline APC & Novocastra & EMM43 & Colon & $\begin{array}{l}\text { PT module, } \\
\text { EDTA }\end{array}$ & $1: 40,60^{\prime}$ & $\begin{array}{l}\text { Membrane and } \\
\text { cytoplasmic }\end{array}$ \\
\hline $\mathrm{Bcl} 2$ & Novocastra & 3.1 & Tonsil & $\begin{array}{l}\text { PT module, } \\
\text { EDTA }\end{array}$ & $1: 150,60^{\prime}$ & $\begin{array}{l}\text { Membrane and } \\
\text { cytoplasmic }\end{array}$ \\
\hline Chromogranin A & DAKO & DAK-A3 & Carcinoid tumor & $\begin{array}{l}\text { PT module, } \\
\text { citrate }\end{array}$ & $1: 200,30^{\prime}$ & Cytoplasmic \\
\hline CK $(5 / 6 / 18)$ & Novocastra & LP34 & Lung & $\begin{array}{l}\text { Pronase E }\left(10^{\prime},\right. \\
\text { RT) }\end{array}$ & $1: 100,60^{\prime}$ & Cytoplasmic \\
\hline CK20 & DAKO & KS20.8 & Colon & $\begin{array}{l}\text { Pronase E }\left(10^{\prime},\right. \\
\text { RT) }\end{array}$ & $1: 50,30^{\prime}$ & Cytoplasmic \\
\hline CK7 & DAKO & KS20.8 & Lung & $\begin{array}{l}\text { Pronase E }\left(10^{\prime},\right. \\
\text { RT) }\end{array}$ & $1: 50,30^{\prime}$ & Cytoplasmic \\
\hline Cyclin D1 & Novocastra & P2D11F11 & Breast carcinoma & $\begin{array}{l}\text { PT module, } \\
\text { EDTA }\end{array}$ & $1: 30,60^{\prime}$ & Nuclear \\
\hline EGFR & Zymed & $31 \mathrm{G} 7$ & Respiratory epithelia & $\begin{array}{l}\text { Pronase E }\left(10^{\prime},\right. \\
\text { RT) }\end{array}$ & $1: 20,30^{\prime}$ & $\begin{array}{l}\text { Membrane and } \\
\text { cytoplasmic }\end{array}$ \\
\hline ERCC1 & Thermo & $8 \mathrm{~F} 1$ & Tonsil & $\begin{array}{l}\text { PT module, } \\
\text { EDTA }\end{array}$ & $1: 100,60^{\prime}$ & Nuclear \\
\hline HER2 & DAKO & Polyclonal & Breast carcinoma & $\begin{array}{l}\text { PT module, } \\
\text { citrate }\end{array}$ & $1: 200,30^{\prime}$ & Membrane \\
\hline Ki67 & DAKO & MIB-1 & Small cell carcinoma & $\begin{array}{l}\text { PT module, } \\
\text { citrate }\end{array}$ & $1: 50,30^{\prime}$ & $\begin{array}{l}\text { Nuclear except } \\
\text { mitotic cells }\end{array}$ \\
\hline LRP & Novocastra & 9D6 & Ileon & $\begin{array}{l}\text { PT module, } \\
\text { EDTA }\end{array}$ & $1: 300,30^{\prime}$ & Cytoplasmic \\
\hline MRP-1 & Novocastra & $33 \mathrm{~A} 6$ & Colon & $\begin{array}{l}\text { PT module, } \\
\text { citrate }\end{array}$ & $1: 50,60^{\prime}$ & Cytoplasmic \\
\hline P53 & DAKO & DO-7 & Skin & $\begin{array}{l}\text { PT module, } \\
\text { citrate }\end{array}$ & $1: 50,30^{\prime}$ & $\begin{array}{l}\text { Nuclear and } \\
\text { cytoplasmic }\end{array}$ \\
\hline RB & Novocastra & $13 \mathrm{~A} 10$ & Tonsil & $\begin{array}{l}\text { PT module, } \\
\text { EDTA }\end{array}$ & $1: 50,60^{\prime}$ & Nuclear \\
\hline TTF1 & DAKO & $8 \mathrm{G} 7 \mathrm{G} 3 / 1$ & Small cell carcinoma & $\begin{array}{l}\text { PT module, } \\
\text { EDTA }\end{array}$ & $1: 100,60^{\prime}$ & Nuclear \\
\hline
\end{tabular}

26 (57.8\%) with BA/lepidic pattern, 15 (33.3\%) with solid pattern, $5(11.1 \%)$ with papillary and 15 (33.3\%) with micropapillary pattern were registered.

Thirteen cases $(28.9 \%)$ showed lymph node metastasis as follows: acinar pattern was present in 13 cases (100\%); solid and micropapillary patterns were present in 3 cases each $(23 \%)$; and papillary pattern in 2 cases $(15.4 \%)$. Two metastasis with solid pattern belonged to primary adenocarcinomas which harbored, respectively, acinar and BA/lepidic and acinar, BA/lepidic and micropapillary patterns.

Seventeen cases $(37.8 \%)$ were diagnosed in men and twenty-eight cases (62.2\%) in women. Age at diagnosis ranged from 44 to 85 years with a median of 67 years. Fourteen cases (31.1\%) were diagnosed in smokers ( 8 males and 6 females), four (8.9\%) in ex-smokers (3 males and 1 female) and twenty-seven (60\%) in never smokers $(6$ males and 21 females). Female patients were more frequently nonsmokers than men $(p=0.0251)$.

Seventeen cases $(37.8 \%)$ were diagnosed as stage IA (5 males/12 females), twelve (26.7\%) as IB (2 males/10 females), ten (22.2\%) as IIA ( 8 males/2 females) and six (13.3\%) as stage IIIA (2 males/4 females). Females were diagnosed more frequently in lower stages when compared to men $(p=0.029)$. There were no differences between stages according to smoking habits.

All adenocarcinomas $(n=45)$ expressed CK7. No expression was observed for CK20, HWMC or chromogranin A. TTF1 was expressed in the great majority of lung adenocarcinomas, with statistical significant higher expression in acinar pattern $(p=0.0094)$, micropapillary pattern $(p=0.012)$ and BA/lepidic patterns $(p=0.00046)$. The expression was significantly higher in BA/lepidic pattern when compared to solid pattern $(p=0.021)$.

Nuclear expression of P53 was statistically higher in all patterns when compared to normal tissue $(p<0.05)$, without differences between patterns.

RB expression was higher in micropapillary pattern when compared to normal tissue $(p=0.011)$. The other patterns showed no differences from basal expression in normal tissue.

There were no significant differences between primary adenocarcinomas and their metastasis, except for cyclin D1 whose expression was higher in the metastasis when compared to the primary neoplasia $(p=0.0409)$. 
Table 3 TTF1, KI67, P53, RB, APC, BCL2, Ciclin D1, ERCC1, MRP1, LRP, HER2 and EGFR expression according to adenocarcinoma pattern. A - acinar; B - BA/lepidic; C - papillary; D - micropapillary and $\mathrm{E}$ - solid patterns. Expression categories: $0=(-)=0-10 \%$; $1=(+)=11-100 \% ; 2=(++)=101-200 \% ; 3=(+++)=201-300 \%$.

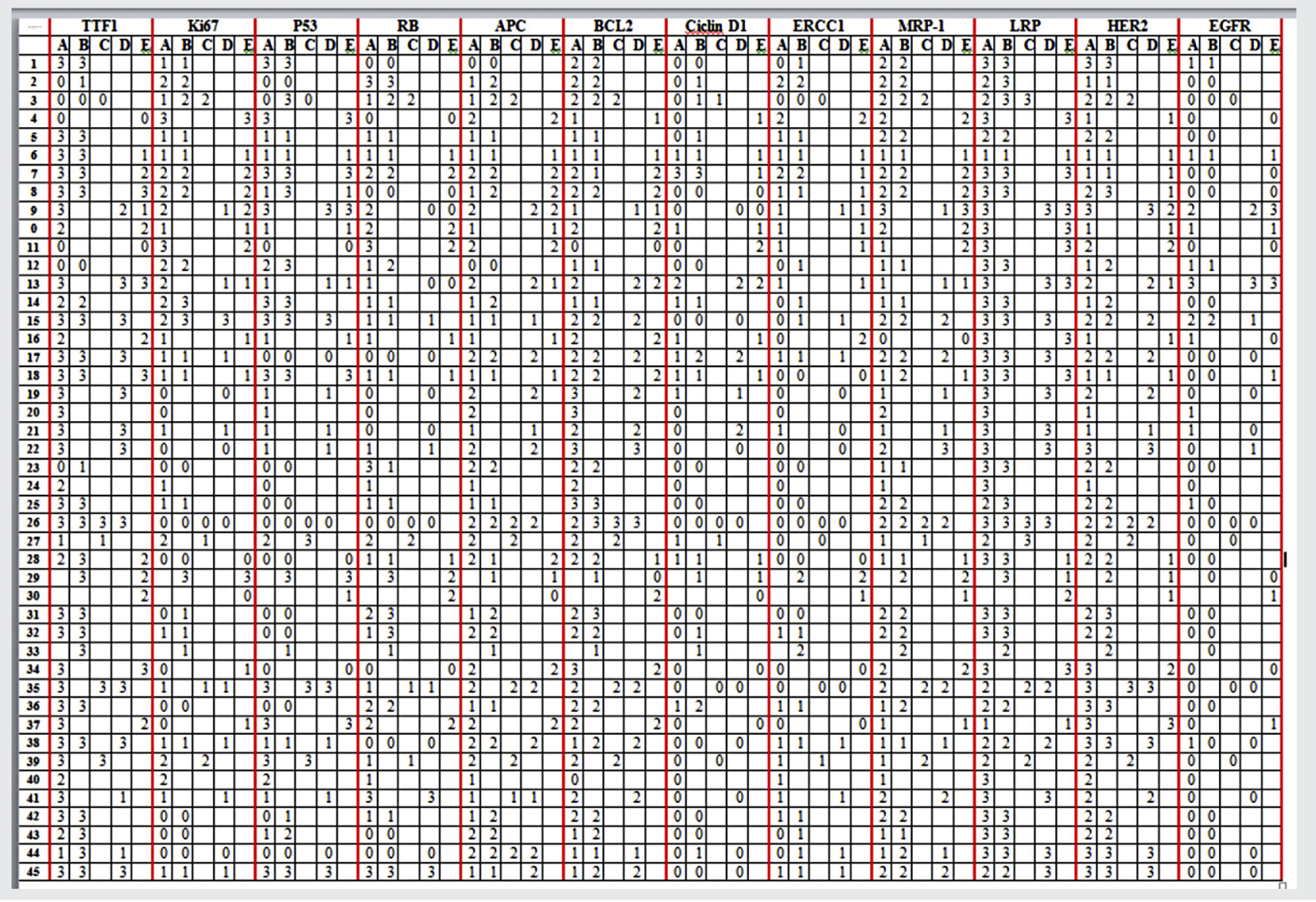

APC expression was higher in all patterns when compared to normal tissues $(p<0.05)$, with no differences between patterns.

BCL2 expression was higher in all patterns studied than normal adjacent tissue $(p<0.05)$, without differences between patterns.

Cyclin D1 expression differed between normal tissue and solid $(p=0.0002)$ and BA/lepidic $(p=0.002)$ patterns, being higher in these patterns than in the normal tissue.

EGFR protein expression was higher in acinar $(p=0.033)$ and solid $(p=0.012)$ patterns when compared to normal tissues, concerning membrane expression only. If we take into account cytoplasmic expression the overall expression was significantly higher in all patterns without differences between them.

For HER2 we observed significantly higher expression in all patterns compared to normal tissue $(p<0.05)$. Expression is also higher in acinar, papillary, micropapillary and $\mathrm{BA} /$ lepidic patterns compared to solid pattern $(p<0.05)$.

ERCC1 expression was lower in acinar $(p=0.0016)$ and papillary $(p=0.019)$ patterns compared to normal tissue. Expression in the other patterns revealed no differences to basal expression in normal tissue. Papillary pattern has significant less expression than solid $(p<0.05)$ and BA/lepidic patterns $(p<0.05)$.
Ki67 expression was higher in all adenocarcinoma patterns when compared to normal lung tissue $(p<0.05)$. There were no differences between the patterns.

LRP expression was different (higher) between normal and the different patterns of the adenocarcinomas $(p<0.05)$.

MRP-1 expression was higher in all patterns compared to normal lung tissue, without differences between patterns $(p<0.05)$.

Some immunohistochemical results are illustrated in Fig. 1.

The analysis of the dendrogram clearly showed that adenocarcinoma is genetically different from normal tissue (Fig. 2). Concerning the patterns, BA/lepidic and acinar are the more similar and papillary the most distinct or genetically separated pattern. By PCA analysis (Fig. 3) we were able to identify three clusters: the first composed of papillary pattern adenocarcinomas; the second corresponding to solid; and the third to the group of acinar, BA/lepidic and micropapillary patterns.

Looking at gender, we have identified higher expression of ERCC1 in female patients when compared to males $(p=0.0008)$. We did not find any differences according to age. HER2 expression was higher in adenocarcinomas of non-smokers or ex-smokers $(p=0.0384)$. Ki67 expression 

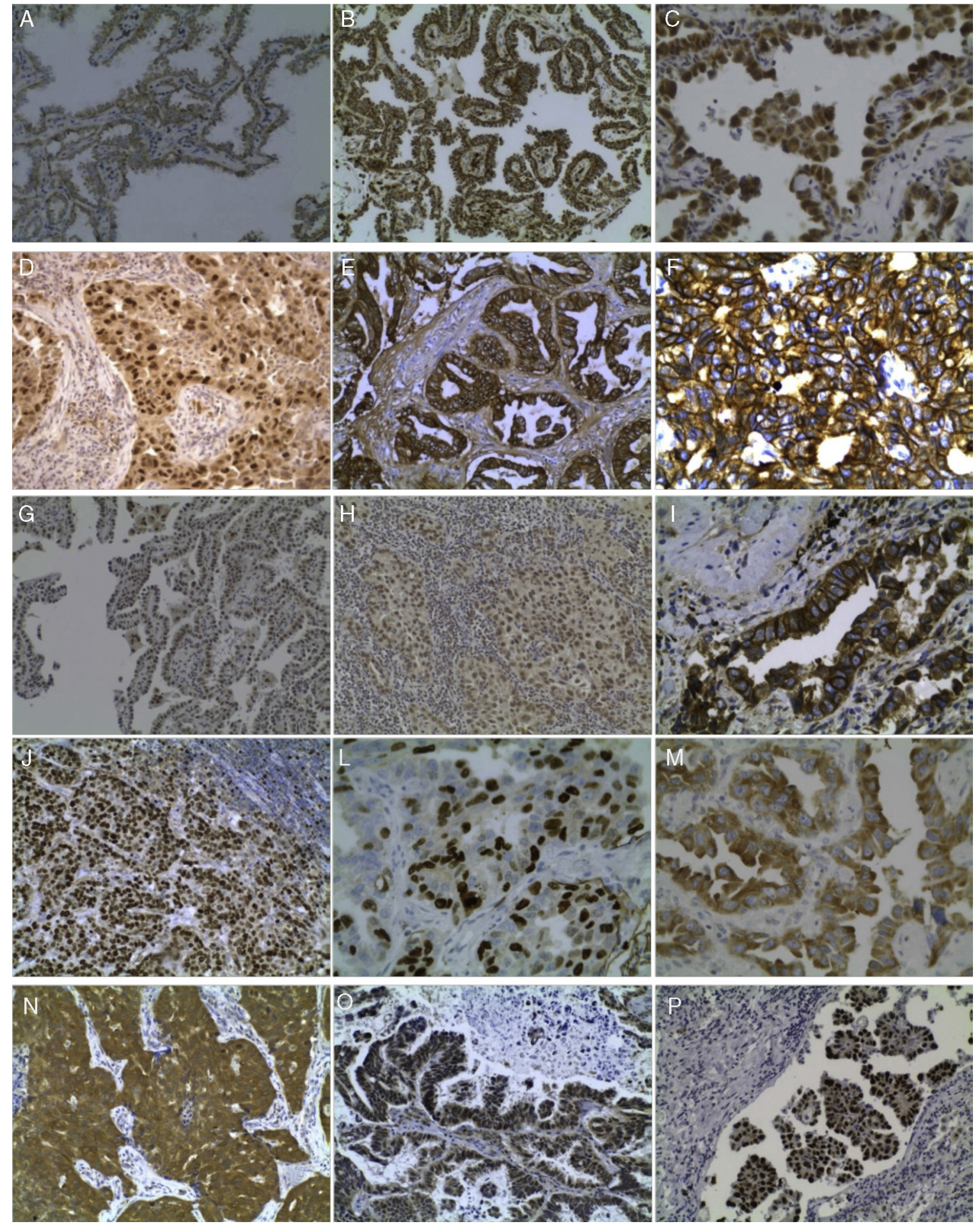

Figure 1 (A) Expression (++) of APC in BA pattern, 200×; (B) Expression (+++) of BCL2 in papillary pattern, 200×; (C) BA pattern with Cyclin D1 expression, 400×; (D) Cyclin D1 expression in solid pattern, 200×; (E) EGFR expression (+++) in acinar pattern, 200×; (F) EGFR expression (+++) in solid pattern, 200×; (G) ERCC1 expression (++) in BA pattern, 200×; (H) ERCC1 expression (++) in solid pattern, 200×; (I) HER2 expression (++) in acinar pattern, 400×; (J) Ki67 expression (+++) in lymph node metastasis, 200×; (L) Ki67 expression (+++) in acinar pattern, 400×; (M) LRP expression (+++) in acinar pattern, 400×; (N) MRP-1 expression (+++) in solid pattern, 200x; (O) RB expression (++) in papillary pattern, 200x; and (P) P53 expression (+++) in micropapillary pattern, 200×. 


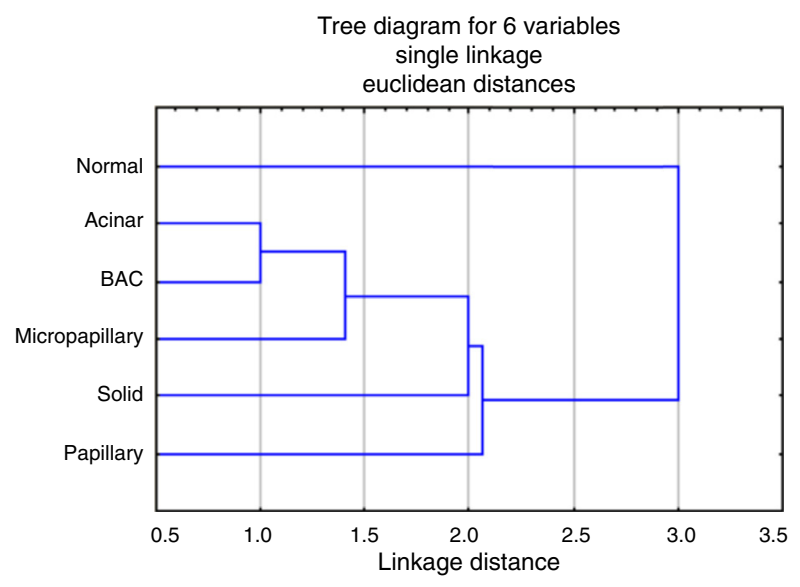

Figure 2 Dendrogram for the hierarchical clustering analysis of transcripts according to their expression values, using Single linkage algorithm, Euclidean distances, targeting the various patterns and normal tissue.

was higher in adenocarcinomas of smokers and ex-smoker patients $(p=0.0034$ and $p=0.0064)$.

TTF1, Ki67, APC, RB, P53, BCL2, ERCC1 and EGFR showed significantly different expressions according to the stage of the tumor. TTF1 expression showed differences between stage IA and IIIA, being higher in stage IA $(p=0.02)$. Ki67 was higher in IIIA compared to IA and IIA $(p=0.02$ and $p=0.02)$. APC expression was higher in IIA and IIIA compared to IA $(p=0.065$ and $p=0.025)$. RB expression was higher in stage IB tumors compared to stage IA $(p=0.04)$. P53 expression was higher in IIA, IB and IIIA compared to IA $(p=0.01 ; p=0.03 ; p=0.01)$. BCL2 expression was higher for IB compared to IA $(p=0.039)$. ERCC1 was higher in stage IA compared to IIA $(p=0.02)$ and in IIIA compared to IIA

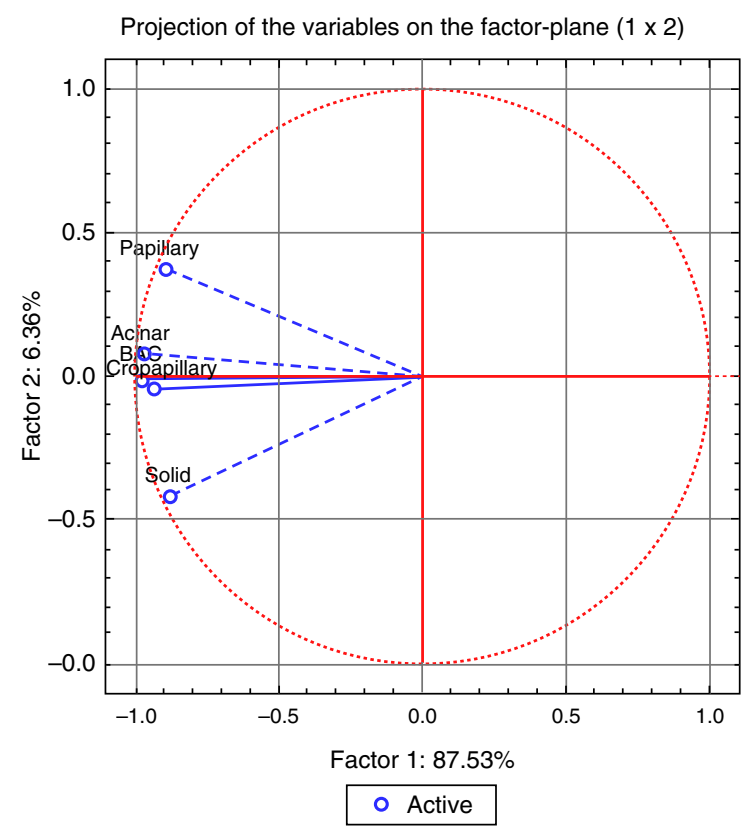

Figure 3 The correlation of the patterns with the advanced PCA factor analysis. $(p=0.01)$. EGFR expression was lower in stage IB compared to IA $(p=0.032)$.

To sum up, almost all patterns showed differences of expression in relation to normal tissues with some exceptions for cyclin D1 (papillary and micropapillary patterns), for EGFR membrane staining (papillary and micropapillary patterns), for ERCC1 (in micropapillary, solid and BA/lepidic patterns), for RB (in acinar, papillary and solid patterns) and for TTF1 (in papillary and solid patterns).

Solid pattern demonstrated lower HER2 expression compared to acinar, papillary, micropapillary and BA/lepidic patterns. Papillary pattern had lower ERCC1 expression than solid and BA/lepidic patterns. Solid pattern showed lower TTF1 expression than BA/lepidic pattern.

\section{Discussion}

Non-BA/lepidic adenocarcinomas are most often peripheral tumors with different growth patterns considered mixed type according to WHO classification, with at least two individual patterns; solid or acinar patterns are the most frequent in the central tumoral bulk and BA/lepidic at the periphery. Acinar has been described as the most common pure subtype and the most common in the mixed type. Papillary pattern was present in $10 \%$ of the adenocarcinomas, often difficult to differentiate from BA/lepidic, which has important therapeutic strategies' implications. ${ }^{9}$ Micropapillary pattern is characterized by small papillary tufts growing from alveolar septa or floating within alveolar spaces lacking fibrovascular cores and is usually observed with papillary and mixed patterns; they are more aggressive due to their increased capacity for metastasize, indicating unfavorable prognosis. ${ }^{9}$ Solid pattern with mucin production has been reported in $15 \%$ of mixed-type adenocarcinomas. ${ }^{9,10}$ BA/lepidic pattern shows tumor cell growth along alveolar septa and aerogeneous spread through the lung. It is frequently diagnosed in former and non-smoking women. BA/lepidic is classified as non-mucinous, mucinous or mixed. ${ }^{9,10,38}$

\section{Markers of differentiation}

CK20, HWMC and chromogranin A were negative in all our samples and CK7 and TTF1 were positive, which means morphology almost always sustains bronchial-pulmonary adenocarcinomas' diagnosis when mucin is not present. These results corroborated those that have been described in the literature. CK7 is positive in $90-100 \%$ and CK20 is positive in only $7-10 \%$ of primary lung adenocarcinomas. ${ }^{39}$ Chromogranin $\mathrm{A}$ is not expressed in an ordinary adenocarcinoma. ${ }^{40}$ TTF1 is a useful marker for lung adenocarcinoma and is also expressed in thyroid normal tissue and tumors. ${ }^{22}$ The use of TTF1, as a differentiation marker, is useful not only for diagnostic purpose but especially to differentiate between different histological types of bronchial and TRU adenocarcinomas. 


\section{Genetic expression in each pattern of} bronchial-pulmonary adenocarcinoma

\section{Acinar pattern}

Starting with membrane proteins that play a central role in the control of cellular proliferation, differentiation, apoptosis and angiogenesis, EGFR and HER2 had a higher expression in acinar pattern than in normal epithelium/lung cells, highlighting the importance of AKT/mTOR, PI3K and MAPK pathways, essential for oncogenic transformation and tumor maintenance. ${ }^{41}$ Blockage of both results in apoptosis and tumor shrinkage. ${ }^{42,43}$ AKT, by inhibiting GSK-3, changes canonical Wnt pathway, releasing $\beta$-catenin, and leading to angiogenesis and proliferation. ${ }^{44}$

TTF1 positivity was statistically higher in the adenocarcinomas (with acinar pattern) compared to normal tissue. While the majority of the adenocarcinomas expresses TTF1, this marker is misunderstood, because its positivity is associated inversely with proliferation but it is correlated with P53 expression and HER2/neu involved in lung cancer. ${ }^{45}$ TTF1, NKX2-8 and PAX9 are very important in initiation and progression of lung cancer. It is said that MAPKinase, JAK/STAT and Wnt are important in activation of TTF1 and NKX8, connected with EGFR and Her2. ${ }^{46}$

The expression of cyclin D1 was higher in tumoral than in normal tissue and RB expression had no statistical difference when compared to normal tissue. This fact may indicate a tendency to proliferate, because once cyclin D1 is in high concentration, it could phosphorylate more RB protein and release E2F, involved in the regulation of genes with implications in cell cycle progression (G1 to $\mathrm{S}$ phase). ${ }^{43,47}$ One of the genes that correlate with E2F is Ki67, still a good marker for proliferative index. ${ }^{48}$ We obtained statistical significant higher expression of Ki67 in all patterns of adenocarcinoma, indicating active proliferative activity. ${ }^{49}$ Another overexpressed gene in this pattern was P53 and some studies indicate that "a low level of p53 leads to transient growth arrest and cell survival, whereas a high level promotes irreversible apoptosis"', and P53 levels may have oscillations, and it has to be explored as a target for therapy. ${ }^{50}$ ERCC 1 is downregulated in acinar pattern, may be indicating that DNA repair pathway is not activated in the acinar pattern. ERCC1 is associated with radio resistance, so it is important for treatment choice. ${ }^{51}$ High BCL2 expression may favor cell cycle arrest.

LRP and MRP1 were also overexpressed in our samples, as has been described in lung cancer. ${ }^{52,53}$ As mentioned these genes can lead to chemotherapy resistance. This fact should be taken into consideration when assessing prognosis and treatment issues.

APC was also overexpressed in the acinar pattern, and being involved in $\beta$-catenin degradation is important in progression, with GSK-3 and Axin downregulating $\beta$ catenin (leading to $\beta$-catenin degradation). ${ }^{54}$ Our findings also suggest that $\beta$-catenin may be downregulated, already described in lung cancer, which is related to cell invasion and metastasis. ${ }^{55} \beta$-Catenin is connected to cytoskeleton and cadherins and regulates $\mathrm{E}$ - or $\mathrm{N}$-cadherin-mediated cell adhesion. Notch activation (that inactivates $\beta$-catenin) may repress $\mathrm{E}$-cadherin, leading to tumor growth and metastasis. ${ }^{56}$ So, overexpression of APC leads to $\beta$-catenin degradation that weakens cell adhesion promoting tumor growth and metastasis.

In relation to the acinar pattern the genes analyzed expressions could lead to cell proliferation and survival, angiogenesis and metastasis.

\section{Papillary pattern}

This pattern showed some differences compared to acinar pattern. There were no differences of expression for cyclin D1 and TTF1, compared with normal tissue. Since cyclin D1 level is not upregulated as well as RB gene, the concentration of active E2F must be regular. However Ki67 was overexpressed, in contrast to previous findings. ${ }^{21}$ So other pathways could explain cellular proliferation. There was higher expression of EGFR but just in cytosol compartment; membrane EGFR had the same level of expression as normal tissue, so we can conclude that activity of EGFR is normal. Thus, all pathways that this gene regulates are functioning normally or if activated, this activation is not induced by EGFR. ${ }^{41,57,58}$

Papillary pattern proliferation properties could in part be explained by APC upregulation when compared to normal tissue.

\section{Micropapillary pattern}

Micropapillary pattern is characterized by small papillary tufts and is considered an aggressive adenocarcinoma, more than papillary pattern. ${ }^{59-61}$ There were three differences with papillary patterns concerning expression of ERCC1, RB and TTF1. RB expression was downregulated in micropapillary, being almost non-existent. Some authors said that downregulation of RB leads to the progression of cell cycle. ${ }^{62}$ Micropapillary pattern had a basal level of ERCC1, this indicating that DNA repair may occur with NER activation. TTF1 was overexpressed in this pattern and, according with what has been said before, this fact indicates lung cancer progression and development after the terminal respiratory unit. These considerations are consistent with our results because downregulation of RB and TTF1 overexpression are responsible for cell cycle progression and basal level of ERCC1 allows DNA repair. This last consideration is very important to keep in mind in treating lung cancer.

\section{Solid pattern}

Genetic expression in this pattern is identical to acinar pattern with only two differences for ERCC1 and TTF1 expressions. These showed no differences compared to normal tissue in solid pattern, whereas in acinar pattern there was a higher expression for TTF1 and downregulation for ERCC1. A lower TTF1 expression reflects a lower differentiation of this pattern and eventually means a more aggressive behavior since in general less differentiated tumors are more aggressive. Higher EGFR expression could be the reflex of EGFR mutations and/or overexpression activating several pathways involved in cell cycle control, proliferation and even metastization. EGFR overexpression is also associated with poor prognosis. ${ }^{33,63}$ Solid pattern has more ERCC1 expression than acinar and this aspect is very important because ERCC 1 repairs DNA and confers resistance to some drugs. ${ }^{51}$ 


\section{BA/lepidic pattern}

BA pattern, called lepidic in ATS/ERS proposed classification can be difficult to distinguish morphologically from papillary pattern. ${ }^{12}$ Cyclin D1 had higher expression in BA/lepidic pattern and a basal level in papillary pattern. This fact and knowing that RB was not overexpressed, enhances the idea that this pathway leads to cell progression. As TTF1 is related with tumor progression and is overexpressed, unlike in papillary pattern, and ERCC1 has a basal level in $\mathrm{BA} /$ lepidic pattern and is downregulated in papillary pattern, this may explain chemical resistance.

By evaluating the expression of these 13 genes, BA/lepidic pattern has more cell progression pathways activated than papillary pattern. This finding proves that they are biologically different. The differences could be explained by the origin in TRU with the different activated pathways, with probable implication in the prognosis and treatment, knowing that different pathways are targets for therapeutic approach.

\section{Metastasis analysis}

Metastasis formation is a complex process with several pathways activated leading to loss of cellular adhesion, increased motility and invasiveness. ${ }^{55}$ Acinar pattern metastasis had cyclin D1 over-expression, statistically different between primary and metastatic tumor. This gene is involved in cell progression that might be helping cell survival in circulation and colonization. ${ }^{55}$

\section{Gender, age, smoking and tumor staging}

ERCC1 expression was higher in females, correlating in some studies to a better prognosis. ${ }^{64}$ However ERCC1 may confer resistance to cisplatin. ${ }^{65}$

Lung adenocarcinoma is more frequently diagnosed in patients over 60 years and it is infrequent before age 40 and generally more aggressive. ${ }^{66}$ All our samples were taken from patients older than the age of 40 . There were no difference in the expression of the markers studied between the group under and over 60 years.

Concerning smoking history, HER2 expression was higher in non-smokers than in ex-smokers. Ki67 expression was higher in tumors of smokers and ex-smoker patients than in non-smokers, indicating a higher proliferative rate and more aggressive/mitotically active tumors.

Women diagnosed with adenocarcinoma were more frequently non-smokers, reflecting the cultural tobacco habits and some of those adenocarcinomas belonging to the group of adenocarcinomas diagnosed in women, non-smokers and young that could harbor EGFR mutations. ${ }^{67}$ Adenocarcinomas diagnosed in women patients were more frequently diagnosed at stages $I A$ and $I B$ reflecting somehow a less aggressive behavior demonstrated also by a lower proliferative index in these stages. Tobacco habits could also explain the activation of different pathways and genetic alterations in these cases. Our results also demonstrated a relation between higher Ki67 expression and smoking habits.

Many gene products have their expression altered when correlating with stage, such as APC, BCL2, EGFR, ERCC1, Ki67, P53, RB and TTF1, showing that gene expression is a dynamic and unforeseen process. From stage IA to IB we observed lower Bcl2 and EGFR expressions and RB higher expression. From stage IB to IIA we observed higher BCl2 and lower ERCC1 expressions. IIIA stage showed higher ERCC1 and Ki67 expressions. From IA and IB to IIA we observed also higher $\mathrm{APC}$ and $\mathrm{Bcl} 2$ expressions. In advanced stages we observed especially higher Ki67, APC and ERCC1 expressions and lower TTF1 expression, the last reflecting a lower differentiation and even a non-TRU adenocarcinoma with a more aggressive behavior. Ki67 higher expression in higher stages was an expected result as it reflects higher proliferation index and thus aggressive behavior. APC mutations were described in several tumors. ${ }^{17}$ Taking into account our results, it seems that APC genetic and pathways changes are important to consider in advanced stages of adenocarcinomas.

One of the most important molecule in this study was P53 because it was higher expressed in all patterns and is involved in several pathways and mechanisms in normal cell cycle, carcinogenesis and DNA repair with obvious therapeutic implications. Some authors relate P53 with MRP1, because their parallel increase is frequent. It was demonstrated that P53 wild-type suppressed MRP1 promoter. These hypotheses are corroborated by our data, because we always obtained high expression of MRP1 and P53. According to these authors P53 was mutated in all patterns. ${ }^{68}$

RB expression was lower in micropapillary pattern, which also explained a more aggressive phenotype because free E2F activates transcription of genes related with tumor progression.

TTF1 was connected with P53 and HER2 in lung cancer and some authors relate this protein with initiation and progression in lung carcinogenesis. ${ }^{19,23}$ The relation between TTF1 and HER2 was observed between solid and BA/lepidic patterns, because both gene expression was higher in BA/lepidic pattern than in solid.

\section{Conclusions}

Female adenocarcinoma patients were more frequently nonsmokers and diagnosed in earlier stages, with higher ERCC1 expression involved in DNA repair.

Advanced stages (IIA and IIIA) of adenocarcinomas showed higher Ki67, APC, ERCC1 expressions and lower TTF1 expression reflecting a more aggressive, mitotically active and less differentiated adenocarcinoma and eventually a non-TRU adenocarcinoma.

There was generally higher expression of the products of genes studied in the adenocarcinomas compared to normal adjacent cells reinforcing their importance in lung adenocarcinoma carcinogenesis.

There were two specific gene expressions with differences between patterns, HER2 and TTF1 that interfere with gene transcription. Papillary and solid patterns revealed less TTF1 expression, identical to normal tissue exhibiting a non-TRU/bronchial phenotype. At the other end acinar, BA/lepidic and micropapillary showed higher TTF1 expression. Solid pattern revealed also lower HER2 and higher EGFR and ERCC1 (this compared to papillary) expression. Papillary showed higher HER2 and lower ERCC1 expressions. Adenocarcinomas showed higher TTF1 expression (type TRU) in 
acinar, BA/lepidic and micropapillary patterns, micropapillary with higher RB expression, acinar with lower ERCC1 and higher EGFR. Ciclin D1 seems to have more importance in acinar and BA/lepidic patterns than in micropapillary.

ERCC1 protein expression in micropapillary, solid and BA/lepidic patterns indicates DNA repair and in acinar and papillary patterns there was lower expression. BCL2 was overexpressed in all patterns, suggesting that there is inhibition of apoptosis. MRP-1and LRP were overexpressed in all patterns and it is important to further analyze these proteins for a better understanding of the response to therapy.

By hierarchical clustering test we highlight papillary pattern as the most different pattern followed by solid pattern; acinar and BA/lepidic patterns are most alike. Using PCA analysis we realized that acinar, micropapillary and BA/lepidic patterns are the most alike, so we made three clusters of patterns: papillary, solid and micropapillary/acinar/lepidic (BA).

Furthers studies are needed in order to interpret these results regarding therapeutic response in advanced staged bronchial-pulmonary carcinomas.

\section{Ethical disclosures}

Protection of human and animal subjects. The authors declare that no experiments were performed on humans or animals for this study.

Confidentiality of data. The authors declare that they have followed the protocols of their work center on the publication of patient data.

Right to privacy and informed consent. The authors declare that no patient data appear in this article.

\section{Funding}

Funded by a grant from CIMAGO, Faculty of Medicine, University of Coimbra, Portugal.

\section{Conflicts of interest}

The authors declare that they have no conflicts of interest.

\section{References}

1. Haegebarth A, Clevers $\mathrm{H}$. Wht signaling, lgr5, and stem cells in the intestine and skin. Am J Pathol. 2009;174:715-21. PubMed PMID: 19197002. Pubmed Central PMCID: 2665733.

2. Lodish HJED, Berk A, Kaiser CA, Lodish HF, Darnell J, Scott MP, et al. Molecular cell biology. 5th ed. New York: W.H. Freeman \& Co Ltd.; 2003.

3. Lee PN, Forey BA, Coombs KJ. Systematic review with metaanalysis of the epidemiological evidence in the 1900s relating smoking to lung cancer. BMC Cancer. 2012;12:385. PubMed PMID: 22943444. Pubmed Central PMCID: 3505152.

4. Massion PP, Carbone DP. The molecular basis of lung cancer: molecular abnormalities and therapeutic implications. Respir Res. 2003;4:12. PubMed PMID: 14641911. Pubmed Central PMCID: 314397.

5. Peto R, Darby S, Deo H, Silcocks P, Whitley E, Doll R. Smoking, smoking cessation, and lung cancer in the UK since 1950: combination of national statistics with two case-control studies. BMJ. 2000;321:323-9. PubMed PMID: 10926586. Pubmed Central PMCID: 27446.

6. Siegel R, Naishadham D, Jemal A. Cancer statistics, 2013. CA Cancer J Clin. 2013;63:11-30. PubMed PMID: 23335087.

7. Tomashefski JF Jr, Cagle PT, Farver CF, Fraire AE. In: Tomashefski JF Jr, editor. Dail and Hammar's pulmonary pathology. 3rd ed. New York: Springer; 2008.

8. Wistuba II, Gazdar AF. Lung cancer preneoplasia. Annu Rev Pathol. 2006;1:331-48. PubMed PMID: 18039118.

9. Tomashefski JF, Cagle PT, Farver CF, Fraire AE. Dail and Hammar's pulmonary pathology. 3rd ed. New York: Springer; 2008.

10. Travis WD, Brambilla E, Müller-Hermelink HK, Harris CC. Pathology genetics of tumours of the lung, pleura, thymus and heart. In: Tumours L, editor. WHO. Lyon: IARC Press; 2004.

11. Travis WD, Brambilla E, Noguchi M, Nicholson AG, Geisinger $\mathrm{K}$, Yatabe $\mathrm{Y}$, et al. Diagnosis of lung cancer in small biopsies and cytology: implications of the 2011 International Association for the Study of Lung Cancer/American Thoracic Society/European Respiratory Society classification. Arch Pathol Lab Med. 2013;137:668-84. PubMed PMID: 22970842.

12. Travis WD, Brambilla E, Noguchi M, Nicholson AG, Geisinger KR, Yatabe $Y$, et al. International association for the study of lung cancer/american thoracic society/european respiratory society international multidisciplinary classification of lung adenocarcinoma. J Thorac Oncol: Off Publ Int Assoc Study Lung Cancer. 2011;6:244-85. PubMed PMID: 21252716.

13. Neves LR, Oshima CT, Artigiani-Neto R, Yanaguibashi G, Lourenco LG, Forones NM. Ki67 and p53 in gastrointestinal stromal tumors-GIST. Arq Gastroenterol. 2009;46:116-20. PubMed PMID: 19578612.

14. Scholzen T, Gerdes J. The Ki-67 protein: from the known and the unknown. J Cell Physiol. 2000;182:311-22. PubMed PMID: 10653597.

15. Woo T, Okudela K, Yazawa T, Wada N, Ogawa N, Ishiwa N, et al. Prognostic value of KRAS mutations and Ki-67 expression in stage I lung adenocarcinomas. Lung Cancer. 2009;65:355-62. PubMed PMID: 19162366.

16. Mori S, Ito G, Usami N, Yoshioka H, Ueda Y, Kodama Y, et al. p53 apoptotic pathway molecules are frequently and simultaneously altered in nonsmall cell lung carcinoma. Cancer. 2004;100:1673-82. PubMed PMID: 15073856.

17. Gotz R. Inter-cellular adhesion disruption and the RAS/RAF and beta-catenin signalling in lung cancer progression. Cancer Cell Int. 2008;8:7. PubMed PMID: 18492263. Pubmed Central PMCID: 2427011.

18. Gong Y, Somwar R, Politi K, Balak M, Chmielecki J, Jiang X, et al. Induction of BIM is essential for apoptosis triggered by EGFR kinase inhibitors in mutant EGFR-dependent lung adenocarcinomas. PLoS Med. 2007;4:e294. PubMed PMID: 17927446. Pubmed Central PMCID: 2001209.

19. Adjei AA. Blocking oncogenic Ras signaling for cancer therapy. J Natl Cancer Inst. 2001;93:1062-74. PubMed PMID: 11459867.

20. Myong NH. Cyclin D1 overexpression, p16 loss, and pRb inactivation play a key role in pulmonary carcinogenesis and have a prognostic implication for the long-term survival in non-small cell lung carcinoma patients. Cancer Res Treat: Off J Korean Cancer Assoc. 2008;40:45-52. PubMed PMID: 19688048. Pubmed Central PMCID: 2697490.

21. Eymin B, Gazzeri S, Brambilla C, Brambilla E. Distinct pattern of E2F1 expression in human lung tumours: E2F1 is upregulated in small cell lung carcinoma. Oncogene. 2001;20:1678-87. PubMed PMID: 11313916.

22. Schettino C, Bareschino MA, Maione P, Rossi A, Ciardiello F, Gridelli $C$. The potential role of pharmacogenomic and genomic in the adjuvant treatment of early stage non-small cell lung cancer. Curr Genomics. 2008;9:252-62. PubMed PMID: 19452042. Pubmed Central PMCID: 2682934. 
23. Kalikaki A, Kanaki M, Vassalou H, Souglakos J, Voutsina A, Georgoulias V, et al. DNA repair gene polymorphisms predict favorable clinical outcome in advanced non-small-cell lung cancer. Clin Lung Cancer. 2009;10:118-23. PubMed PMID: 19362955.

24. Simon GR, Sharma S, Cantor A, Smith P, Bepler G. ERCC1 expression is a predictor of survival in resected patients with non-small cell lung cancer. Chest. 2005;127:978-83. PubMed PMID: 15764785.

25. Deeley RG, Cole SP. Substrate recognition and transport by multidrug resistance protein 1 (ABCC1). FEBS Lett. 2006;580:1103-11. PubMed PMID: 16387301.

26. Konig J, Hartel M, Nies AT, Martignoni ME, Guo J, Buchler MW, et al. Expression and localization of human multidrug resistance protein $(\mathrm{ABCC})$ family members in pancreatic carcinoma. Int $\mathrm{J}$ Cancer. 2005;115:359-67. PubMed PMID: 15688370.

27. Berger W, Setinek U, Hollaus P, Zidek T, Steiner E, Elbling L, et al. Multidrug resistance markers $\mathrm{P}$-glycoprotein, multidrug resistance protein 1, and lung resistance protein in non-small cell lung cancer: prognostic implications. J Cancer Res Clin Oncol. 2005;131:355-63. PubMed PMID: 15856298.

28. Bouhamyia L, Chantot-Bastaraud S, Zaidi S, Roynard P, Prengel C, Bernaudin JF, et al. Immunolocalization and cell expression of lung resistance-related protein (LRP) in normal and tumoral human respiratory cells. J Histochem Cytochem: Off J Histochem Soc. 2007;55:773-82. PubMed PMID: 17438350.

29. Filipits M, Haddad V, Schmid K, Huynh A, Dunant A, Andre F, et al. Multidrug resistance proteins do not predict benefit of adjuvant chemotherapy in patients with completely resected non-small cell lung cancer: International Adjuvant Lung Cancer Trial Biologic Program. Clin Cancer Res: Off J Am Assoc Cancer Res. 2007;13:3892-8. PubMed PMID: 17606722.

30. Fridman E, Skarda J, Pinthus JH, Ramon J, Mor Y. Expression of multidrug resistance-related protein (MRP-1), lung resistancerelated protein (LRP) and topoisomerase-II (TOPO-II) in Wilms' tumor: immunohistochemical study using TMA methodology, vol. 152. Olomouc, Czechoslovakia: Biomedical Papers of the Medical Faculty of the University Palacky; 2008. p. 47-51. PubMed PMID: 18795074.

31. Hembruff SL, Laberge ML, Villeneuve DJ, Guo B, Veitch Z, Cecchetto $M$, et al. Role of drug transporters and drug accumulation in the temporal acquisition of drug resistance. BMC Cancer. 2008;8:318. PubMed PMID: 18980695. Pubmed Central PMCID: 2596802.

32. Shigematsu H, Takahashi T, Nomura M, Majmudar K, Suzuki M, Lee $\mathrm{H}$, et al. Somatic mutations of the HER2 kinase domain in lung adenocarcinomas. Cancer Res. 2005;65:1642-6. PubMed PMID: 15753357.

33. Wu SG, Chang YL, Hsu YC, Wu JY, Yang CH, Yu CJ, et al. Good response to gefitinib in lung adenocarcinoma of complex epidermal growth factor receptor (EGFR) mutations with the classical mutation pattern. Oncologist. 2008;13:1276-84. PubMed PMID: 19060236.

34. Jang TW, Oak CH, Chang HK, Suo SJ, Jung MH. EGFR and KRAS mutations in patients with adenocarcinoma of the lung. Korean J Intern Med. 2009;24:48-54. PubMed PMID: 19270482. Pubmed Central PMCID: 2687655.

35. Jo UH, Han SG, Seo JH, Park KH, Lee JW, Lee HJ, et al. The genetic polymorphisms of HER-2 and the risk of lung cancer in a Korean population. BMC Cancer. 2008;8:359. PubMed PMID: 19055823. Pubmed Central PMCID: 2661000.

36. Katzel JA, Fanucchi MP, Li Z. Recent advances of novel targeted therapy in non-small cell lung cancer. J Hematol Oncol. 2009;2:2. PubMed PMID: 19159467. Pubmed Central PMCID: 2637898.

37. Edge SB, Byrd DR, Compton CC, Fritz AG, Greene FL, Trotti A. AJCC cancer staging manual. New York: Springer; 2010.

38. Zell JA, Ou SH, Ziogas A, Anton-Culver H. Epidemiology of bronchioloalveolar carcinoma: improvement in survival after release of the 1999 WHO classification of lung tumors. J Clin Oncol: Off J Am Soc Clin Oncol. 2005;23:8396-405. PubMed PMID: 16293870.

39. Ikeda S, Fujimori M, Shibata S, Okajima M, Ishizaki Y, Kurihara T, et al. Combined immunohistochemistry of beta-catenin, cytokeratin 7, and cytokeratin 20 is useful in discriminating primary lung adenocarcinomas from metastatic colorectal cancer. BMC Cancer. 2006;6:31. PubMed PMID: 16451736. Pubmed Central PMCID: PMC1373659.

40. Pelosi G, Pasini F, Sonzogni A, Maffini F, Maisonneuve P, lannucci A, et al. Prognostic implications of neuroendocrine differentiation and hormone production in patients with Stage I nonsmall cell lung carcinoma. Cancer. 2003;97:2487-97. PubMed PMID: 12733148.

41. Matsuzawa Y, Kiuchi Y, Toyomura K, Matsumoto I, Nakamura H, Fujino $\mathrm{H}$, et al. Activation of cytosolic phospholipase A2alpha by epidermal growth factor (EGF) and phorbol ester in HeLa cells: different effects of inhibitors for EGF receptor, protein kinase C, Src, and C-Raf. J Pharmacol Sci. 2009;111:182-92. PubMed PMID: 19783865.

42. Marinov M, Ziogas A, Pardo OE, Tan LT, Dhillon T, Mauri FA, et al. AKT/mTOR pathway activation and BCL-2 family proteins modulate the sensitivity of human small cell lung cancer cells to RAD001. Clin Cancer Res: Off J Am Assoc Cancer Res. 2009;15:1277-87. PubMed PMID: 19228731.

43. Sos ML, Fischer S, Ullrich R, Peifer M, Heuckmann JM, Koker $M$, et al. Identifying genotype-dependent efficacy of single and combined PI3K- and MAPK-pathway inhibition in cancer. Proc Natl Acad Sci U S A. 2009;106:18351-6. PubMed PMID: 19805051. Pubmed Central PMCID:2757399.

44. Kubba LA, McCluggage WG, Liu J, Malpica A, Euscher ED, Silva EG, et al. Thyroid transcription factor-1 expression in ovarian epithelial neoplasms. Mod Pathol. 2008;21:485-90. PubMed PMID: 18246044.

45. Barlesi F, Pinot D, Legoffic A, Doddoli C, Chetaille B, Torre JP, et al. Positive thyroid transcription factor 1 staining strongly correlates with survival of patients with adenocarcinoma of the lung. Br J Cancer. 2005;93:450-2. PubMed PMID: 16052216. Pubmed Central PMCID: 2361585.

46. Hsu DS, Acharya CR, Balakumaran BS, Riedel RF, Kim MK, Stevenson $M$, et al. Characterizing the developmental pathways TTF-1, NKX2-8, and PAX9 in lung cancer. Proc Natl Acad Sci U S A. 2009;106:5312-7. PubMed PMID: 19279207. Pubmed Central PMCID: 2664027.

47. Tyczynski JE, Bray F, Parkin DM. Lung cancer in Europe in 2000: epidemiology, prevention, and early detection. Lancet Oncol. 2003;4:45-55. PubMed PMID: 12517539.

48. Su YC, Hsu YC, Chai CY. Role of TTF-1, CK20, and CK7 immunohistochemistry for diagnosis of primary and secondary lung adenocarcinoma. Kaohsiung J Med Sci. 2006;22:14-9. PubMed PMID: 16570563.

49. Francesconi CM, Hutcheon AE, Chung EH, Dalbone AC, Joyce NC, Zieske JD. Expression patterns of retinoblastoma and E2F family proteins during corneal development. Investig Ophthalmol Vis Sci. 2000;41:1054-62. PubMed PMID: 10752941.

50. Zhang XP, Liu F, Wang W. Coordination between cell cycle progression and cell fate decision by the p53 and E2F1 pathways in response to DNA damage. J Biol Chem. 2010;285:31571-80. PubMed PMID: 20685653. Pubmed Central PMCID: 2951231.

51. Hwang IG, Ahn MJ, Park BB, Ahn YC, Han J, Lee S, et al. ERCC1 expression as a prognostic marker in N2(+) nonsmall-cell lung cancer patients treated with platinum-based neoadjuvant concurrent chemoradiotherapy. Cancer. 2008;113:1379-86. PubMed PMID: 18623378.

52. Kang HK, Lee E, Pyo H, Lim SJ. Cyclooxygenase-independent down-regulation of multidrug resistance-associated protein-1 expression by celecoxib in human lung cancer cells. Mol Cancer Ther. 2005;4:1358-63. PubMed PMID: 16170027. 
53. Rolff J, Dorn C, Merk J, Fichtner I. Response of patient-derived non-small cell lung cancer xenografts to classical and targeted therapies is not related to multidrug resistance markers. J Oncol. 2009;2009:814140. PubMed PMID: 19547715. Pubmed Central PMCID: 2696640.

54. Farr GH 3rd, Ferkey DM, Yost C, Pierce SB, Weaver C, Kimelman D. Interaction among GSK-3, GBP, axin, and APC in Xenopus axis specification. J Cell Biol. 2000;148:691-702. PubMed PMID: 10684251. Pubmed Central PMCID: 2169372.

55. Wu X, Zhu Y, Yan H, Liu B, Li Y, Zhou Q, et al. Isothiocyanates induce oxidative stress and suppress the metastasis potential of human non-small cell lung cancer cells. BMC Cancer. 2010;10:269. PubMed PMID: 20534110. Pubmed Central PMCID: 2891640.

56. Panelos J, Batistatou A, Paglierani M, Zioga A, Maio V, Santi $\mathrm{R}$, et al. Expression of Notch-1 and alteration of the Ecadherin/beta-catenin cell adhesion complex are observed in primary cutaneous neuroendocrine carcinoma (Merkel cell carcinoma). Mod Pathol. 2009;22:959-68. PubMed PMID: 19396152.

57. Fakih M, Vincent M. Adverse events associated with anti-EGFR therapies for the treatment of metastatic colorectal cancer. Curr Oncol. 2010;17 Suppl. 1:S18-30. PubMed PMID: 20680104. Pubmed Central PMCID: 2901793.

58. Fakih M, Wong R. Efficacy of the monoclonal antibody EGFR inhibitors for the treatment of metastatic colorectal cancer. Curr Oncol. 2010;17 Suppl. 1:S3-17. PubMed PMID: 20680105. Pubmed Central PMCID: 2901794.

59. Borczuk AC. Micropapillary histology: a frequent morphology of mutation-associated lung adenocarcinoma? Am J Clin Pathol. 2009;131:615-7. PubMed PMID: 19369618.

60. Prior JO, Stupp R, Christodoulou M, Letovanec I. Micropapillary pattern in lung adenocarcinoma: aspect on 18F-fluorodeoxyglucose positron emission tomography/ computed tomography imaging. Interact Cardiovasc Thorac Surg. 2010;10:144-5. PubMed PMID:19875512.
61. De Oliveira Duarte Achcar R, Nikiforova MN, Yousem SA. Micropapillary lung adenocarcinoma: EGFR, K-ras, and BRAF mutational profile. Am J Clin Pathol. 2009;131:694-700. PubMed PMID: 19369630.

62. Moulager M, Corellou F, Verge V, Escande ML, Bouget FY. Integration of light signals by the retinoblastoma pathway in the control of $\mathrm{S}$ phase entry in the picophytoplanktonic cell Ostreococcus. PLoS Genet. 2010;6:e1000957. PubMed PMID: 20502677. Pubmed Central PMCID: 2873908.

63. Jin P, Zhang J, Beryt M, Turin L, Brdlik C, Feng Y, et al. Rational optimization of a bispecific ligand trap targeting EGF receptor family ligands. Mol Med. 2009;15:11-20. PubMed PMID: 19048033. Pubmed Central PMCID: 2592073.

64. Zheng Z, Li X, Schell MJ, Chen T, Boulware D, Robinson L, et al. Thymidylate synthase in situ protein expression and survival in stage I nonsmall-cell lung cancer. Cancer. 2008;112:2765-73. PubMed PMID: 18442042.

65. Tibaldi C, Giovannetti E, Vasile E, Mey V, Laan AC, Nannizzi $S$, et al. Correlation of CDA, ERCC1, and XPD polymorphisms with response and survival in gemcitabine/cisplatin-treated advanced non-small cell lung cancer patients. Clin Cancer Res: Off J Am Assoc Cancer Res. 2008;14:1797-803. PubMed PMID: 18347182.

66. Qian J, Zou Y, Rahman JS, Lu B, Massion PP. Synergy between phosphatidylinositol 3-kinase/Akt pathway and Bcl-xL in the control of apoptosis in adenocarcinoma cells of the lung. Mol Cancer Ther. 2009;8:101-9. PubMed PMID: 19139118. Pubmed Central PMCID: 3110728.

67. Dacic S, Shuai Y, Yousem S, Ohori P, Nikiforova M. Clinicopathological predictors of EGFR/KRAS mutational status in primary lung adenocarcinomas. Mod Pathol. 2010;23:159-68. PubMed PMID: 19855375.

68. Sullivan GF, Yang JM, Vassil A, Yang J, Bash-Babula J, Hait WN. Regulation of expression of the multidrug resistance protein MRP1 by p53 in human prostate cancer cells. J Clin Investig. 2000;105:1261-7. PubMed PMID: 10792001. Pubmed Central PMCID: 315445. 